\title{
Role of Apparent Diffusion Coefficient (ADC) Mapping in Assessment of Therapeutic Response of Hepatocellular Carcinoma Post Trans-Catheter Arterial Chemoembolization
}

\author{
MONA A.S.M. ABO ELENIN, M.Sc.; ZENAT A. EL SABBAGH, M.D. and \\ MOHAMED M.M. ABDEL AZIZ, M.D. \\ The Deparment of Radiodiagnosis, Faculty of Medicine, Ain Shams University \& Maadi Armed Forces Hospital
}

\begin{abstract}
Background: Trans-arterial chemoembolization (TACE) is widely used as an interventional procedure in treatment of HCCs. ADC value can be used in evaluating its efficacy in order to rule out or in residual tumor tissue.

Aim of Study: To assess the role of DWI and ADC value in evaluating HCCs post TACE.

Patients and Methods: A retrospective analytical study on 25 patients with hepatocellular carcinoma (HCC); to assess therapeutic response of (HCC) cases after TACE by ADC mapping MRI technique in comparison to dynamic contrast study (DCE-MRI), to evaluate its accuracy, sensitivity and specificity in detecting treatment response/residual tumor.
\end{abstract}

Results: Comparative study between the 2 groups revealed; highly significant increase in ADC value, in active group; compared to inactive group; with highly significant statistical difference $(p<0.01)$. Comparative study between DCE-MRI and DWI/ADC assessments revealed; non-significant difference in sensitivity, specificity, PPV and NPV in HCC patients; with non-significant difference $(p>0.05)$. Spearman's correlation analysis shows that; AFP level had a highly significant negative correlation with ADC value; with highly significant statistical difference $(p<0.01)$. By using ROC-curve analysis, DWI/ADC value at a cutoff point ( 91.33 ) detected patients with residual active lesions, with good accuracy (84\%), sensitivity $84 \%$ and specificity $83 \%(p=0.0001)$.

Conclusion: ADC maps can be used as a quantitative value to differentiate between active and inactive tumors and in monitoring response to treatment in oncological patients.

Key Words: ADC - Hepatocellular carcinoma - TACE - DWI $-M R I$.

\section{Introduction}

HEPATOCELLULAR carcinoma (HCC) occurs predominantly in patients with underlying chronic liver disease and cirrhosis [1].

Correspondence to: Dr. Mona A.S.M. Abo Elenin, E-Mail: mas.md90@gmail.com
HCC is now the third leading cause of cancer deaths worldwide, with over 500,000 people affected [2].

Liver Transplantation remains the best option for patients with $\mathrm{HCC}$ according to Milan criteria (single tumors $\leq 5 \mathrm{~cm}$ in diameter or no more than three tumors $<3 \mathrm{~cm}$ in diameter). Unfortunately, there is a limited supply of good-quality deceased donor organs. Thus, alternative treatments, including resection, radiofrequency ablation (RFA), and, potentially, systemic therapy are needed [3].

Patients who have advanced disease may benefit from palliative care interventions rather than be subjected to often ineffective therapies [4].

The most commonly offered therapy is transcatheter arterial chemoembolization (TACE). TACE is performed by an interventional radiologist who selectively cannulates the feeding artery to the tumor and delivers high local doses of chemotherapy, including doxorubicin, cisplatin, or mitomycin C. To prevent systemic toxicity, the feeding artery is occluded with gel foam or coils to prevent flow [5].

Unenhanced CT confirms successful introduction of the chemoembolization mixture into the targeted lesions. However, it can be difficult to evaluate contrast enhancement in a tumor with partial retention of iodized oil on contrast- enhanced CT because of the beam hardening artifacts produced by the high attenuation of iodized oil. The signal intensity of MRI is not degraded by the presence of iodized oil; therefore, a residual viable tumor is better defined by MRI [6]

Dynamic contrast-enhanced MRI (DCE MRI) can play a significant role as an imaging biomarker, 
especially in the detection of viable tumor foci, the differentiation between necrosis and viable tumor, and early prediction of treatment response

ADC has the potential to predict the tumor response to treatment weeks before the morphological changes appear. It measures the mobility of water in tissues. Viable tumors are high in cellularity, and the cells have an intact cell membrane that restricts the mobility of water molecules and results in a relatively low ADC. Conversely, cellular necrosis increases membrane permeability, allowing water molecules to move freely and causing a relative increase in ADC. It has become a promising biomarker of tumor response to therapy

Diffusion-weighted imaging (DWI) provides main information about tumor cellularity and cell membrane integrity. So, it may be sensitive to the changes that occur in the tumor microenvironment following treatment. It also can be evaluated quantitatively by calculation of the apparent diffusion coefficient (ADC) [9]

\section{Patients and Methods}

This study was a retrospective study that included 25 patients with HCC lesions who underwent TACE procedure at Maadi Armed Forces hospital over a period of 4 months (from November 2017 till February 2018). Patients underwent dynamic MRI then TACE and follow-up within 3 month by another dynamic MRI.

The patients' ages were between 50 and 73 years there were 21 male patients and 4 female patients. Approval and informed consents were taken from all patients.

\section{Inclusion criteria:}

Definitely diagnosed patient with HCC by DCE MRI who underwent TACE.

\section{All patients has been subjected to the following:}

Clinical assessment.

Laboratory investigations: (AFP, liver functions, serum albumin bilirubin, coagulation profile, $\mathrm{CBC}$ ).

Ultrasound to exclude ascitis.

\section{Exclusion criteria:}

Contraindications to contrast media, e.g. patients with renal failure and patients allergic to contrast media.
Contraindications to magnetic resonance imaging, e.g. claustrophobia, cardiac prosthesis and pace makers and metallic implants and plates.

Technique of MRI:

I- Physician directive:

- Clinical evaluation by complete past and c present history.

- Laboratory studieis including blood creatinine.

\section{II- Patient position:}

- The patient lies supine with arms by the side.

IV- Examination time:

- DCE-MRI for liver examination takes about 30-45 minutes.

\section{IV- Images accquistion:}

All cases underwent baseline and follow-up MR imaging performed using 3 Tesla (GE Discovery 750) MRI machine. Abdominal coil was used with respiratory triggering. The imaging protocol included the following:

a-Pre contrast MR imaging before the diffusion weighted examination:

- T1-weighted images were performed with the following parameters: $(\mathrm{TR}=400 \mathrm{~ms}, \mathrm{TE}=20 \mathrm{~ms}$, $385 \times 385 \mathrm{~mm}$ field of view (FOV), $256 \times 256$ matrix, section thickness $5-7 \mathrm{~mm}$ ).

- T2-weighted images with the following parameters $(\mathrm{TR}=3000 \mathrm{~ms}, \mathrm{TE}=90,385 \times 385 \mathrm{~mm}$ FOV, 256 × 256 matrix and section thickness: 5$7 \mathrm{~mm})$.

- STIR (short time inversion recovery) was performed using the following parameters: $(\mathrm{TR}=$ $418 \mathrm{~ms}, \mathrm{TE}=80, \mathrm{TI}=140 \mathrm{~ms}, 385 \times 385 \mathrm{FOV}, 256$ x 256 matrix and section thickness $5-7 \mathrm{~mm}$ ).

\section{b- Dynamic study:}

- A bolus injection of $0.05 \mathrm{mmol}$ of gadobenate dimeglumine per kilogram of body weight followed by $20 \mathrm{~mL}$ of saline flush at a rate of $2 \mathrm{~mL} / \mathrm{s}$ by using a power injector.

- Three successive Postcontrast images were acquired using a double (early and late) hepatic arterial phase, followed by portal and delayed phases. Early and late arterial phases were performed consecutively and without interruption, with a fixed delay of 15 seconds after the start of contrast material injection and within a breathhold of 20 seconds. The portal venous phase was acquired 30 seconds after the end of the late arterial phase and the delayed phase 175 seconds after the administration of contrast material. 


\section{c- Diffusion weighted images:}

Functional DWI was performed using singleshot spin-echo-planar imaging during one or more breath holds with two $b$-values $\left(500,800 \mathrm{~mm}^{2} / \mathrm{s}\right)$ applied in the $\mathrm{z}$ direction. These $b$-values were chosen to overcome the effect of capillary perfusion and water diffusion in extracellular extra vascular space.

ADC maps were reconstructed from each set of DW Is acquired at each slice position.

\section{Analysis of the MR images:}

Images were sent to the workstation for further image processing.

DWI was used to create ADC maps and subsequently $\mathrm{ADC}$ values were measured and recorded.

ADC maps were assessed both qualitatively by recording the signal intensity and quantitatively by measuring ADC values in the areas of restriction that showed pathological enhancement in the late arterial images.

ADC maps are pixel-based that were generated on the workstation. ADC was estimated with linear regression analysis of the function $\mathrm{S}=\mathrm{S} 0 \exp (-\mathrm{b}$ $\mathrm{ADC}$ ), where $\mathrm{S}$ is the signal intensity after application of the diffusion gradient, and S0 is the signal intensity at a $\mathrm{b}$ value of $0 \mathrm{~s} / \mathrm{mm}^{2}$. Three $b$-values $\left(0,500\right.$, and $\left.800 \mathrm{~s} / \mathrm{mm}^{2}\right)$ were used for ADC calculation.

\section{Statistical analysis:}

Data entry, processing and statistical analysis was carried out using MedCalc ver. 18.2.1 (MedCalc, Ostend, Belgium). Data were presented and suitable analysis was done according to the type of data (parametric and non-parametric) obtained for each variable.

\section{Descriptive statistics:}

Mean, Standard deviation $( \pm S D)$ and range were used to describe parametric numerical data, while Median and Inter-quartile range (IQR) for non-parametric numerical data. Frequency and percentage of non-numerical data.

\section{Analytical statistics:}

Mann-Whitney's U-test was used to assess the statistical significance of the difference of a nonparametric variable between the two study groups.

McNemar's test was used to examine the relationship between two (paired) qualitative variables.
Chi-Square test was used to examine the relationship between two qualitative variables. Correlation analysis (using Spearman's method): To assess the strength of association between two quantitative variables. The correlation coefficient denoted symbolically " $r$ " defines the strength and direction of the linear relationship between two variables.

$p$-value of $>0.05$ was considered statistically non significant $(5 \%)$. $p$-value $<0.05$ was considered signinficant and $>0.01$ was highly significant.

The ROC Curve (receiver operating characteristic) provides a useful way to evaluate the Sensitivity and specificity for quantitative Diagnostic measures that categorize cases into one of two groups.

Kappa statistics to compute the measure of agreement between two investigational methods Kappa's over 0.75 is excellent, 0.40 to 0.75 is fair to good, and below 0.40 is poor.

\section{Results}

Twenty five patients diagnosed with HCC were included in the study and their data were retrospectively analyzed.

Demographic and clinical variables of the patients were summarized in Table (1).

Table (1): Patient's, tumor characteristics and MRI diagnostic data among $25 \mathrm{HCC}$ patients.

\begin{tabular}{ll}
\hline Variables & Mean \pm SD \\
\hline Age (years) & $64.6 \pm 6.8$ \\
Size of lesion $(\mathrm{cm})$ & $3.9 \pm 1.3$ \\
AFP (ng/ml) & $97 \pm 106.6$ \\
Gender: & \\
$\quad$ Male & $21(84 \%)$ \\
$\quad$ Female & $4(16 \%)$ \\
Residence: & \\
$\quad$ Rural & $14(56 \%)$ \\
$\quad$ Urban & $11(44 \%)$ \\
ADC value $\left(\mathrm{x} 10^{3} \mathrm{~mm}^{2} / \mathrm{sec}\right)$ & $1.47 \pm 0.37$ \\
Confined active lesions: & \\
$\quad+$ ve & $13(52 \%)$ \\
\hline
\end{tabular}

\section{Comparative studies:}

The 25 patients were classified according to lesion activity confirmed by subtraction MRI and AFP into 2 independent groups.

The group with active lesions included 13 patients, while the group of inactive lesions included 12 patients. 
Table (2): Comparison between the 2 groups as regards patient's and tumor characteristics using Mann-Whitney's U and Chi square tests.

\begin{tabular}{|c|c|c|c|}
\hline \multirow{2}{*}{ Variables } & $\begin{array}{l}\text { Active group } \\
\quad(n=13)\end{array}$ & $\begin{array}{l}\text { Inactive group } \\
\qquad(\mathrm{n}=12)\end{array}$ & $\begin{array}{c}\text { Mann-Whitney's } \\
\text { U-test }\end{array}$ \\
\hline & Median (IQR) & Median (IQR) & $p$-value \\
\hline Age (years) & $63(57.7-71.2)$ & $64.5(63-68.5)$ & 0.57 \\
\hline Size of lesion $(\mathrm{cm})$ & $4.5(2.8-5.5)$ & $3.2 \quad(2.9-4)$ & 0.11 \\
\hline Variables & $\begin{array}{l}\text { Active group } \\
\text { (13) }\end{array}$ & $\begin{array}{l}\text { Inactive group } \\
\text { (12) }\end{array}$ & $\begin{array}{c}\text { Chi square test } \\
p \text {-value }\end{array}$ \\
\hline \multicolumn{4}{|l|}{ Gender: } \\
\hline Male & $1 \quad(7.7 \%)$ & $3(25 \%)$ & 0.25 \\
\hline Female & $12(92.3 \%)$ & $9(75 \%)$ & \\
\hline \multicolumn{4}{|l|}{ Residence: } \\
\hline Rural & $9 \quad(69.2 \%)$ & $5(41.7 \%)$ & 0.17 \\
\hline Urban & $4 \quad(30.8 \%)$ & $7(58.3 \%)$ & \\
\hline ADC value $\left(x 10 \mathrm{~mm}^{2} / \mathrm{sec}\right)$ & $1.13(1.08-1.26)$ & $1.85(1.76-1.94)$ & 0.000022 \\
\hline
\end{tabular}

Comparison between the 2 groups revealed non-significant difference as regards age, sex, residence and size of lesions ( $p>0.05)$, yet regarding ADC value revealed significance increase in active group with highly significant statistical difference $(p<0.01)$.

The 2 groups were compared regarding demographic criteria and tumor size as shown in (Table 2).

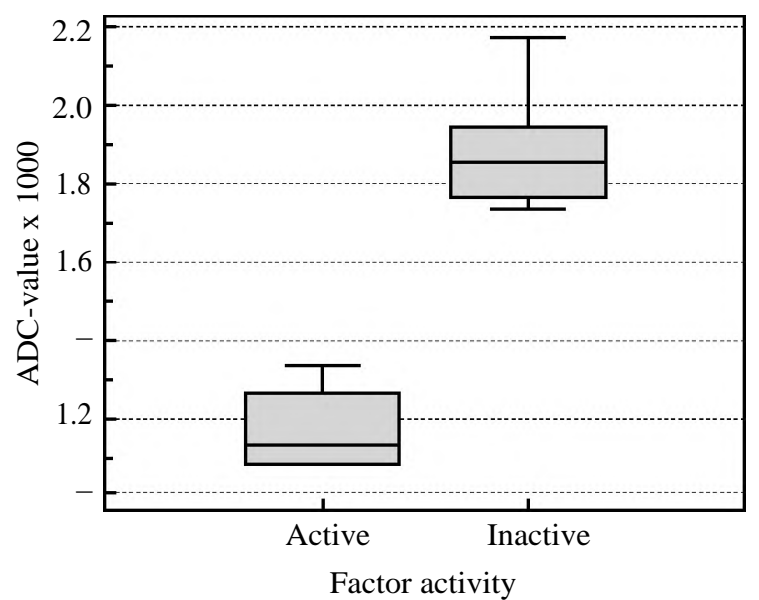

Fig. (1): Box and whisker comparing the 2 groups as regards ADC value.
Table (3): Comparison between DCE-MRI and DWI/ADC as regards diagnostic accuracy for lesion activity assessments: $\mathrm{n}=25$.

\begin{tabular}{lccc}
\hline Variables & $\begin{array}{c}\text { D-MRI } \\
\text { assessment }\end{array}$ & $\begin{array}{c}\text { DWI/ADC } \\
\text { assessment }\end{array}$ & $\begin{array}{c}\text { McNemar's } \\
\text { test } p \text {-value }\end{array}$ \\
\hline $\begin{array}{c}\text { Sensitivity (TPR) } \\
\text { true positive rate) }\end{array}$ & $92.31 \%$ & $84.62 \%$ & $=0.4$ \\
$\begin{array}{c}\text { Specificity (TNR) } \\
\text { true negative rate) }\end{array}$ & $91.67 \%$ & $83.33 \%$ & $=0.38$ \\
$\begin{array}{c}\text { Positive predictive } \\
\text { value (PPV) }\end{array}$ & $92.3 \%$ & $84.6 \%$ & $=0.4$ \\
$\begin{array}{c}\text { Negative predictive } \\
\text { value (NPV) }\end{array}$ & $91.7 \%$ & $83.3 \%$ & $=0.37$ \\
\hline
\end{tabular}

Diagnostic accuracy of DCE-MRI vs DWI/ADC:

DCE-MRI and DWI/ADC assessments regarding lesion activity showed comparable sensitivity, specificity, PPV and NPV in HCC patients; with statistically non-significant difference $(p>0.05)$ as shown in (Table 4) and (Fig. 2). 

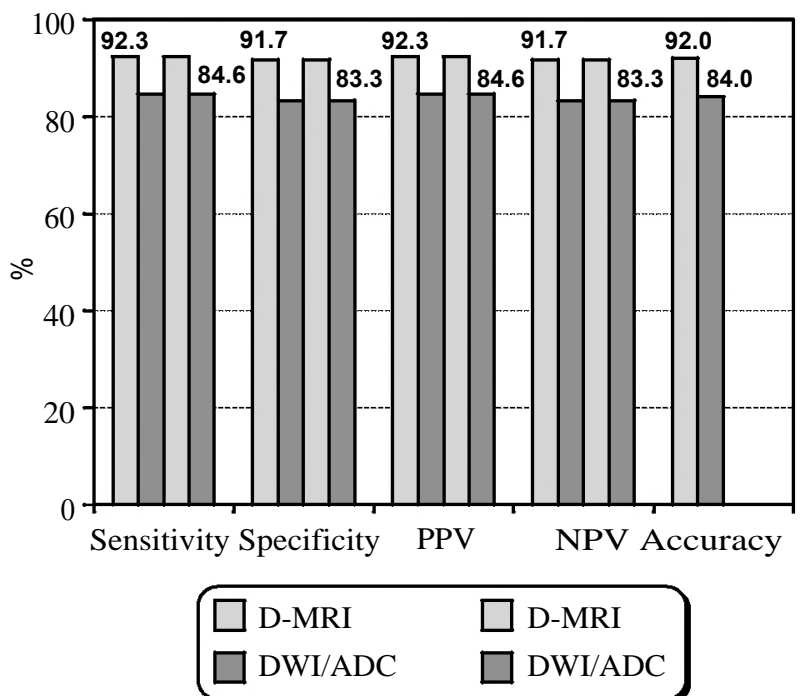

Fig. (2): Comparison between DCE-MRI and DWI/ADC as regards diagnostic accuracy assessments.

Table (4): An agreement between DCE-MRI and DWI/ADC.

\begin{tabular}{|c|c|c|c|c|}
\hline & \multicolumn{2}{|c|}{ DWI/ADC } & \multirow{2}{*}{ Total } & \multirow{2}{*}{$\begin{array}{c}\text { Agreemen } \\
\text { Kappa }\end{array}$} \\
\hline & Negative & Positive & & \\
\hline \multicolumn{5}{|l|}{$D-M R I:$} \\
\hline Negative & 9 & & $312(48 \%)$ & 0.52 \\
\hline Positive & 3 & 10 & $13(52 \%)$ & \\
\hline Total & $12(48 \%)$ & $13(52 \%)$ & $25(100 \%)$ & \\
\hline
\end{tabular}

This table shows a moderate agreement between DCE-MRI and DWI/ADC assessments of reactivity among HCC patients (kappa=0.52).

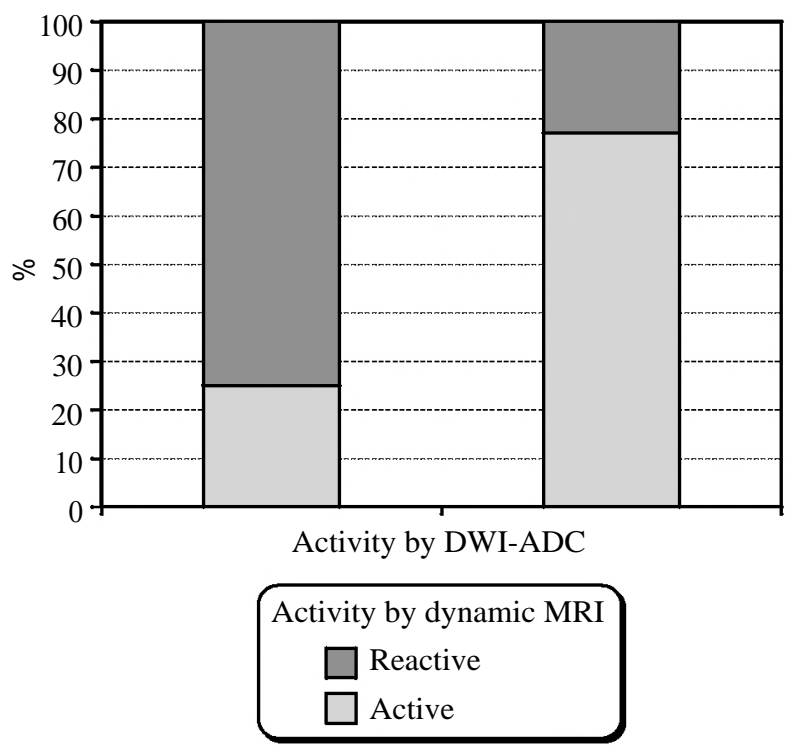

Fig. (3): An agreement between D-MRI and DWI/ADC.
Correlation between patients characteristics and ADC values was evaluated in the study and the results are shown in Table (5).

Table (5): Correlation between patients characteristics and ADC values.

\begin{tabular}{lll}
\hline & \multicolumn{2}{c}{ ADC value } \\
\cline { 2 - 3 } Associated factor & rho & $p$ \\
\hline Age (years) & 0.085 & 0.69 \\
Size of lesion (cm) & -0.3 & 0.15 \\
AFP (ng/ml) & -0.75 & $<0.0001^{* *}$ \\
\hline
\end{tabular}

rho: Spearman's rho (correlation coefficient).

Spearman's correlation analysis showed that; AFP level was negatively corelated with ADC value; with highly significant statistical difference $(p<0.01)$ (Fig. 4).

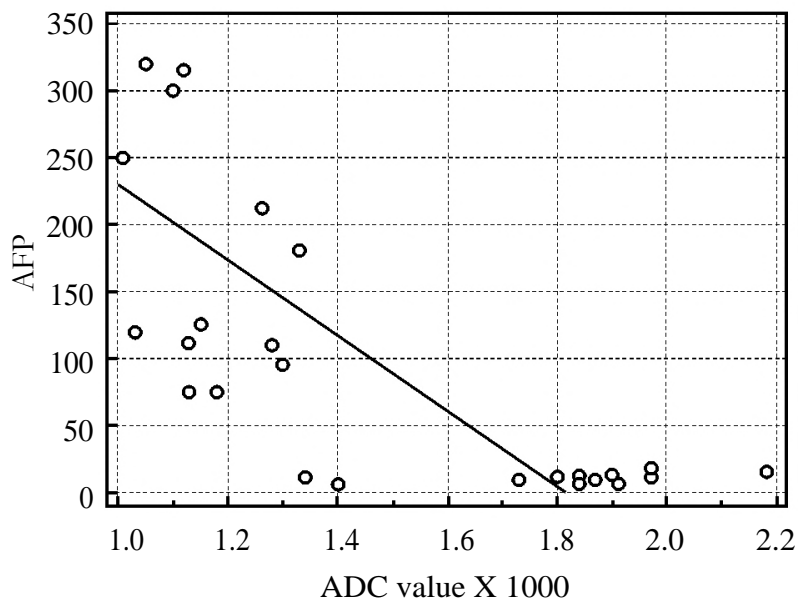

Fig. (4): Correlation between ADC value and AFP level.

ROC curve analysis to detect residual active lesions is shown in Table (6).

Table (6): Roc-curve of DWI/ADC value to detect active patients (13).

\begin{tabular}{lccccccc}
\hline Variable & AUC & SE & $\begin{array}{c}\text { Best cut } \\
\text { off point } \\
\text { (Criterion) }\end{array}$ & $\begin{array}{c}\text { Sensi- Speci- } \\
\text { tivity }\end{array}$ & $\begin{array}{c}\text { ficity } \\
(\%)\end{array}$ & $p$-value \\
\hline D-MRI & 0.920 & 0.0640 & - & 92.31 & 91.67 & $<0.0001^{* *}$ \\
DWI/ & 0.840 & 0.0865 & $\leq 1.33$ & 84.62 & 83.33 & $=0.0001^{* *}$ \\
ADC & & & & & \\
value \\
\hline ROC (Receiver operating characteristic). \\
AUC = Area under curve. \\
SE = Standard Error.
\end{tabular}


By using ROC-curve analysis, DCE-MRI detected patients with residual active lesions, with excellent (92\%) accuracy, sensitivity $=92 \%$ and specificity $=91 \%(p<0.01)$ (Fig. 4).

By using ROC-curve analysis, DWI/ADC value at a cutoff point $(\leq 1.33)$ detected patients with residual active lesions, with good (84\%) accuracy, sensitivity= $84 \%$ and specificity $=83 \%(p=0.0001)$ (Fig. 5).

\section{Illustrative cases:}

A 60 years old female with treated HCV showing a hepatic focal lesion proved to be $\mathrm{HCC}$ at right lobe segment $\mathrm{V}$ measuring $3.5 \times 3 \mathrm{~cm}$. The $\mathrm{CT}$ and Dynamic MRI post TACE were inconclusive yet DWI/ADC sequences showed restricted diffusion within the lesion, also AFP where still high. The patient was scheduled for a 2 nd session of diagnostic and therapeutic angiography which proved the presence of arterial supply to the tumor and injection of chemotherapy was done. Triphasic CT was done 1 month post 1 st session of TACE and Dynamic MRI with DWI/ADC was done 2 months apart.
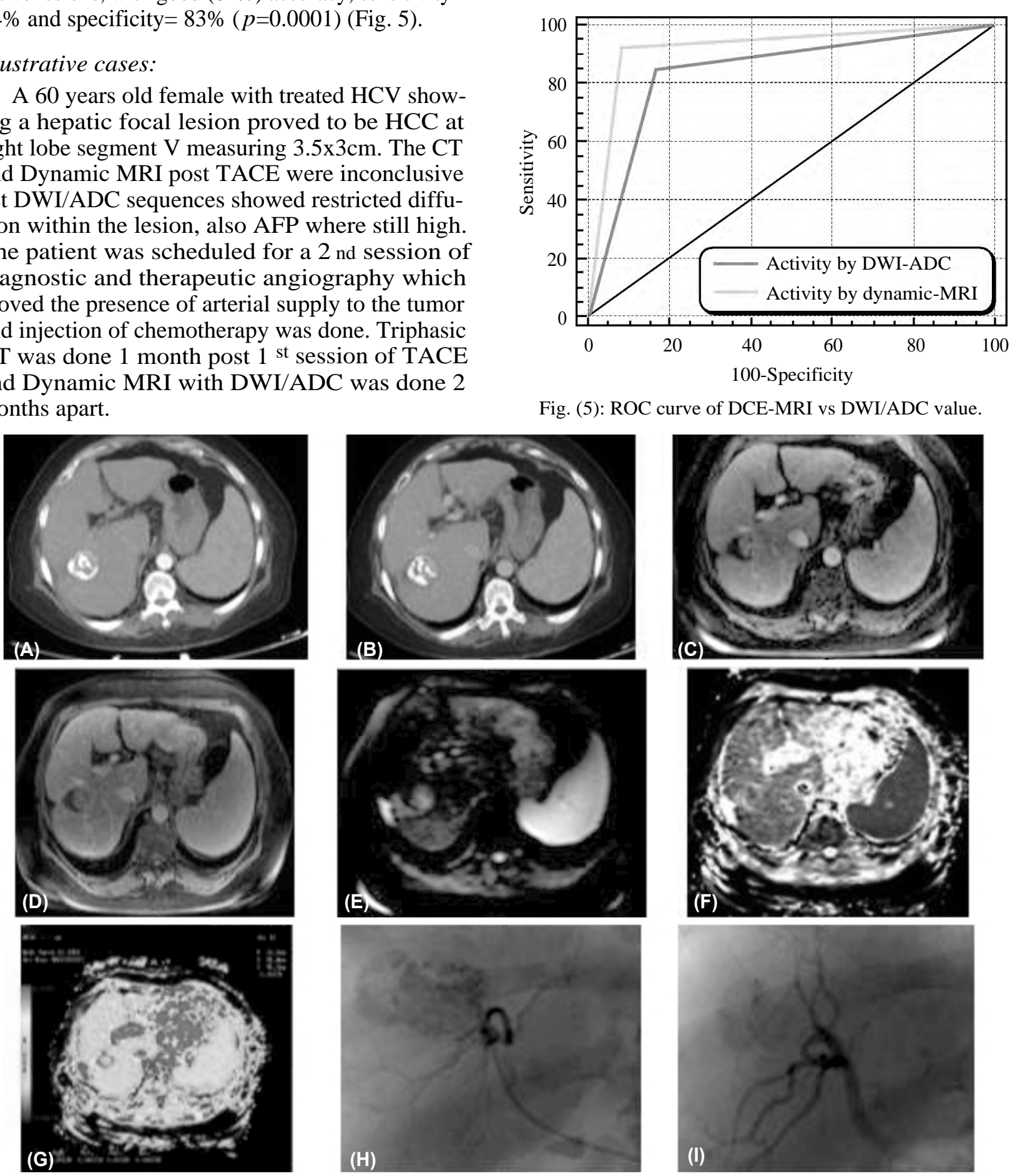

Fig. (5): ROC curve of DCE-MRI vs DWI/ADC value. $\mathrm{HCC}$ at left lobe segment IVa measuring $5 \times 6 \mathrm{~cm}$ underwent TACE. After 3 months follow-up MRI was done with DWI and ADC mapping. The lesion showed residual activity along with elevated AFP so he underwent 2 nd session of TACE.
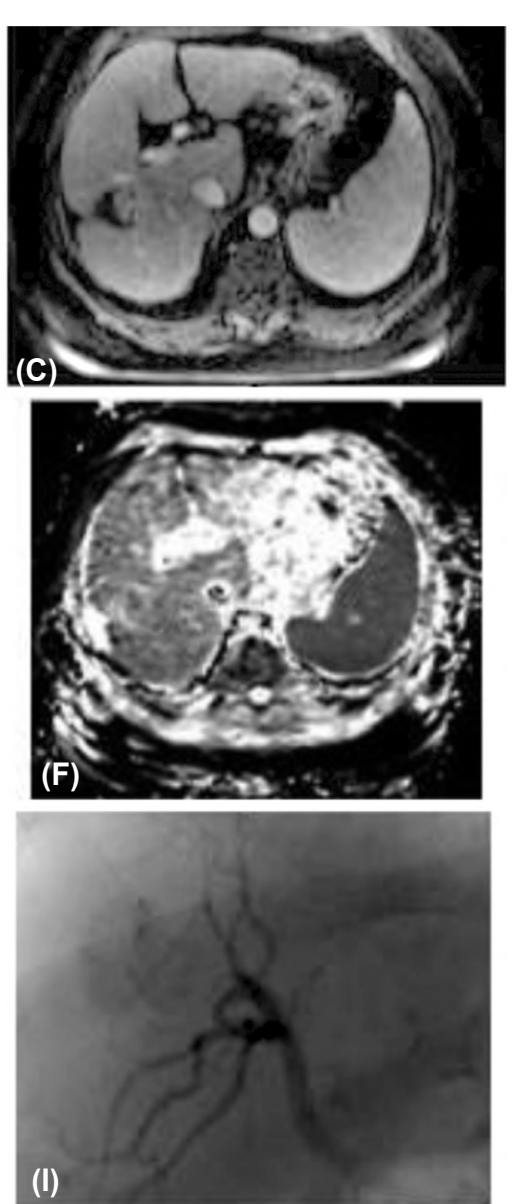

Fig. (6): (A,B) Arterial and delayed phases of triphasic CT showing no definite enhancement or washout. (C,D) Arterial and delayed phases of dynamic MRI showing no appreciable enhancement or washout as well yet (E,F) DWI/ADC sequences showing restricted diffusion within the lesion with (G) Showing low ADC average value about 1.26 suggestive of tumoral activity. (H,I) Angiographic images showing tumoral blush after contrast injection which disappeared after injection of chemolipidol mixture denoting adequate embolization. 

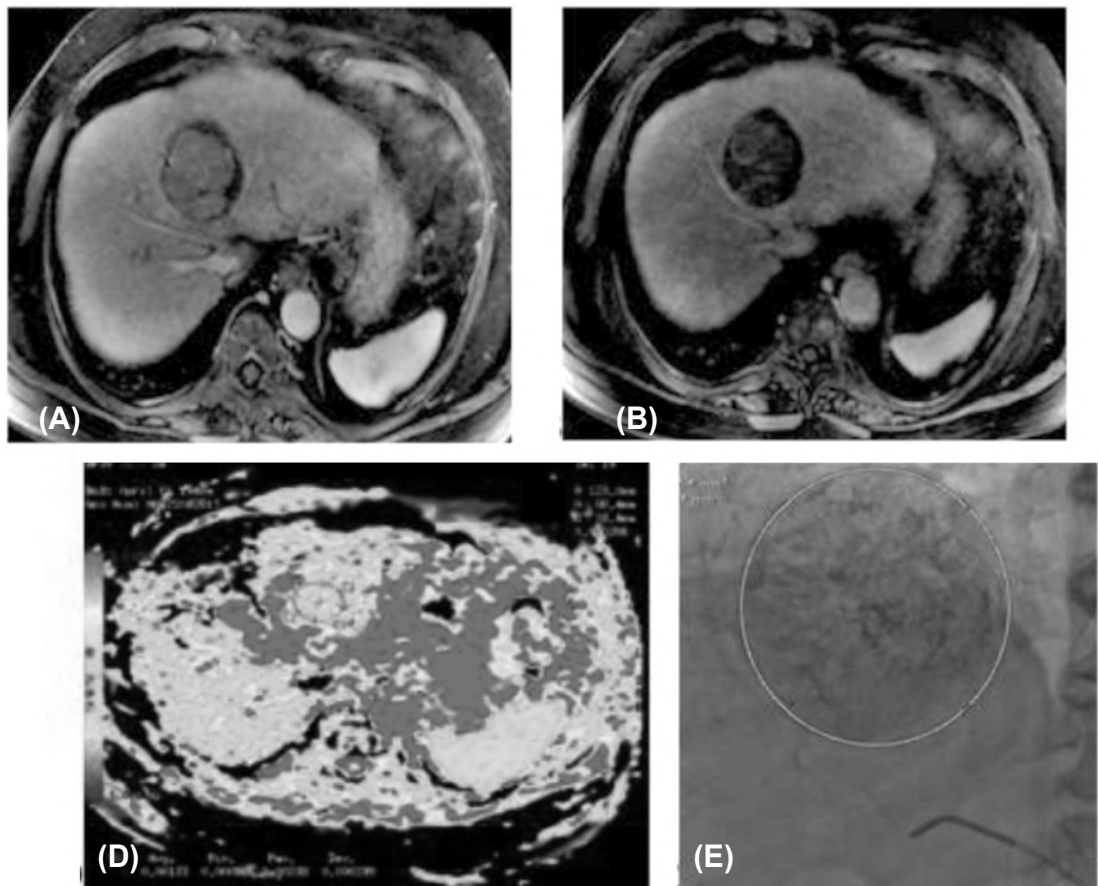
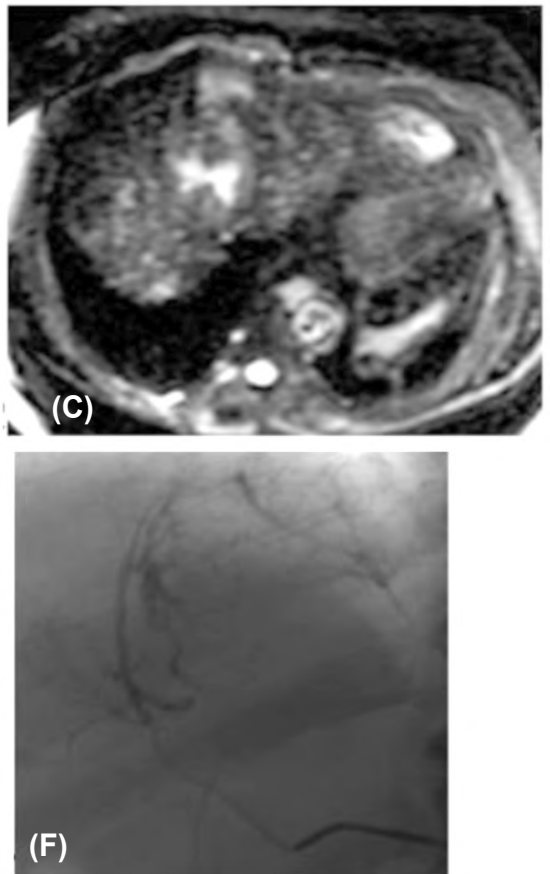

Fig. (7): (A) Early arterial phase of dynamic MRI showing arterial contrast enhancement, (B) Delayed phase showing contrast washout, (C) DWI showing high signal, (D) ADC mapping showing low ADC value denoting restricted diffusion, (E) Angiographic image during 2 nd session of TACE showing tumoral blush denoting residual arterial supply and hence tumoral activity and (D) Post chemo injection showing no tumoral blush denoting adequate embolization.

\section{Discussion}

In this study we used high $b$-values (500 and $800 \mathrm{~s} / \mathrm{mm}^{2}$ ) to overcome the effect of capillary perfusion and water diffusion in extracellular extra vascular space, as high $b$ value will result in reduction in signal from moving protons in the bile ducts, cysts, vessels, and fluid in the bowel. This will result in an increased contrast between the lesion and liver. This was near similar to the $b$ value $\left(500\right.$ and $\left.1000 \mathrm{~s} / \mathrm{mm}^{2}\right)$ used in studies carried out by Koike et al. [10], Demir et al. [11].

Our results agreed with Goshima et al. [12], who observed that diffusion weighted imaging had a $100 \%$ sensitivity, a $65.5 \%$ specificity, a positive predictive value of $67.7 \%$, a negative predictive value of $100 \%$ and an overall agreement of $80 \%$.

Our results correlated a sensitivity of $92 \%$, specificity of $100 \%$, and accuracy of $93 \%$ for the detection of viable tumor after TACE (in $30 \mathrm{HCCs}$ ) using double contrast MRI [superparamagnetic iron oxide (SPIO) and Gd-DTPA agents].

Our study disagreed with Bolog et al. [13] who stated that DWI was not a reliable predictor of local HCC recurrence following TACE compared to gadolinium-enhanced MRI.

The study was limited by its retrospective design. The sample size was small due to the strict selection criteria adopted for this highly specialized indication. This reduced the power of the statistical analysis. The Standard of reference SOR was not based on histology but rather on radiological diagnosis. No biopsies were performed to confirm complete treatment necrosis or residual disease, due to ethical and practical difficulties in performing biopsies in all cases. However patients with residual tumoral activity were subjected to second session of TACE where tumoral viability was confirmed by the presence of arterial supply to the tumor tissue.

\section{Conclusion:}

We conclude that dynamic MRI is valuable and the standard in detecting recurrent lesions however, this value is augmented by the addition of DWI/ ADC protocol which will significantly be of great value in increasing the confidence in our diagnosis.

Conflict of interest: We have no conflict of interest to declare. 


\section{References}

1- MACHIDA K.: NANOG-dependent metabolic reprogramming and symmetric division in tumor-initiating stemlike cells. In Alcohol and Cancer (pp. 105-113). Springer, Cham., 2018

2- LLOVET J.M., PAVEL M., RIMOLA J., DIAZ M.A., COLMENERO J., SAAVEDRA-PEREZ D., FONDEVILA C., AYUSO C., FUSTER J., GINÈS P. and BRUIX J.: Pilot study of living donor liver transplantation for patients with hepatocellular carcinoma exceeding Milan Criteria (Barcelona Clinic Liver Cancer extended criteria). Liver Transplantation, (3): 369-79, 2018.

3- IMURA S., TERAOKU H., YOSHIKAWA M., ISHIKAWA D., YAMADA S., SAITO Y., IWAHASHI S., IKEMOTO T., MORINE Y. and SHIMADA M.: Potential predictive factors for microvascular invasion in hepatocellular carcinoma classified within the Milan criteria. International Journal of Clinical Oncology, 1: 98-103, 2018.

4- FERRI J., DOCKX Y., VONGHIA L.., PAPADIMITRIOU K., RASSCHAERT M., FRANCQUE S., PEETERS M and ROLFO C.: Innovative molecular targeted agents in hepatocellular carcinoma: New gladiators on the arena. Minerva Chirurgica, 72 (3): 206-18, 2017.

5- LIU S., GUO L., LI H., ZHANG B., SUN J., ZHOU C., ZHOU J., FAN J. and YE Q.: Postoperative adjuvant trans-arterial chemoembolization for patients with hepatocellular carcinoma and portal vein tumor thrombus. Annals of Surgical Oncology, 7: 2098-104, 2018.

6- BELLISSIMO F., PINZONE M.R., CACOPARDO B and NUNNARI G.: Diagnostic and therapeutic management of hepatocellular carcinoma. World Journal of Gastroenterology, 21 (42): 12003, 2015.

7- KIERANS A.S., ELAZZAZI M., BRAGA L., LEONAR-
DOU P., GERBER D.A., BURKE C., QURESHI W., KANEMATSU M. and SEMELKA R.C.: Thermoablative treatments for malignant liver lesions: 10-year experience of MRI appearances of treatment response. American Journal of Roentgenology, 194 (2): 523-9, 2010.

8- EBEED A.E., ROMEIH M.A., REFAT M.M. and YOSSEF M.H.: Role of dynamic contrast-enhanced and diffusion weighted MRI in evaluation of hepatocellular carcinoma after chemoembolization. The Egyptian Journal of Radiology and Nuclear Medicine, 48 (4): 807-15, 2017.

9- ELSAID N.A., KADDAH R.O., FATTAH M.S. and SALAMA N.M.: Subtraction MRI versus diffusion weighted imaging: Which is more accurate in assessment of hepatocellular carcinoma after Trans Arterial Chemoembolization (TACE)?. The Egyptian Journal of Radiology and Nuclear Medicine, 47 (4): 1251-64, 2016.

10- KOIKE N., CHO A., NASU K., SETO K., NAGAYA S., OHSHIMA Y. and OHKOHCHI N.: Role of diffusionweighted magnetic resonance imaging in the differential diagnosis of focal hepatic lesions. World journal of gastroenterology: WJG, 15 (46): 5805, 2009.

11- DEMIR Ö.I., OBUZ F., SAGOL O. and DICLE O. Contribution of diffusion-weighted MRI to the differential diagnosis of hepatic masses. Diagnostic and Interventional Radiology, 13 (2): 81, 2007.

12- GOSHIMA S., KANEMATSU M., NODA Y., KONDO H., WATANABE H. and BAE K.T.: Diffusion kurtosis imaging to assess response to treatment in hypervascular hepatocellular carcinoma. American Journal of Roentgenology, 204 (5): W543-9, 2015.

13- BOLOG N., PFAMMATTER T., MÜLLHAUPT B., ANDREISEK G. and WEISHAUPT D.: Double-contrast magnetic resonance imaging of hepatocellular carcinoma after transarterial chemoembolization. Abdominal imaging, 33 (3): 313-23, 2008. 


\section{دور معامل الإنتشار الظاهرى بالرنين الهغناطيسى

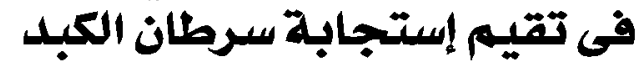

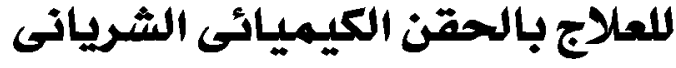

سرطان الكبد هوخامس أكثر سرطان شيوعاً فى العالم وله نتائج سيئة إذا لم يتم علاجه. أن العلاج بالحقن الكيميائى قد أثبت أن له نتائج واعدة اللمرضى الذين لا يسنطيعون اللجوء اللجراحة. ولذلك فقد ازدادت أهمية متابعة استجابة الودم العلاج بعد الحقن الكيميائى فى علم الأوام التصويرى. وذلك لمتابعة استجابة المريض العلاج أو عدمه لتحديد احتياجه لعلاجات أخرى قبل زيادة تطور المرض.

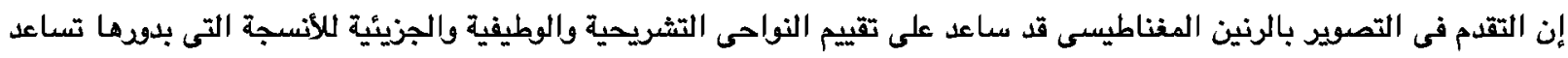
على تقييم الإستجابة العلاج ويوفر معلومات عن التغيرات الشكلية والتغيرات فى محتوى السوائل والتليف لنسيج الكبد.

تالرنين المغناطيسى الديناميكى يمكنه تقييم التغيرات فى الشريان المغذى اللودم فى حين أن معامل الانتشار الظاهرى يستخدم فى تحديد وتقييم البئد الكبدية.

معامل الانتشار الظاهرى يمكن استخدامه كقيمة عددية للتفرقة بين نشاط الودم من عدمه كما يمكن استخدامه لمتابعة الاستجابة للعلاج في مريض السرطان.

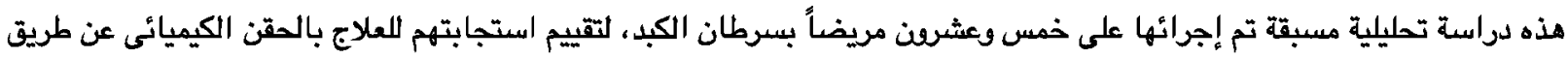

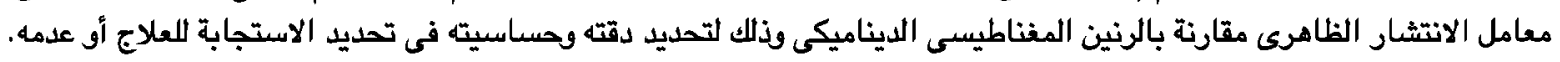

ولذالك فأن الرنين المغناطيسى وسيلة مهمة في متابعة نشاط الودم بعد الحقن الكيميائى. والرنين المغناطيسي الكئي الديناميكى له قيمة كبيرة

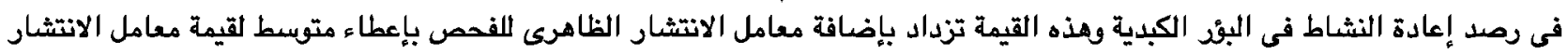
الظاهرى والذى يمكن استخدامه كعامل كمى العي.

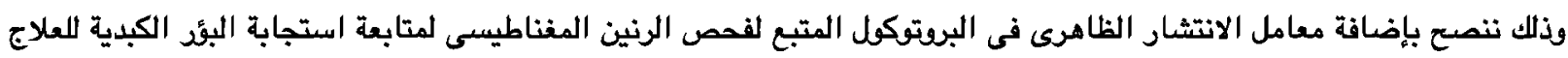
بالحقن الكيميائى لآنه يزيد من الثقة في التشخيص. 